\title{
Certain Basic Concepts of Teaching Turkish as a Foreign Language
}

\author{
Ülker Şen \\ Correspondence: Ülker Şen, Department of Social Science and Turkish Education, Gazi University, Ankara, Turkey.
}

Received: August 19, 2016

doi:10.11114/jets.v4i10.1822
Online Published: August 30, 2016

URL: http://dx.doi.org/10.11114/jets.v4i10.1822

\begin{abstract}
Concept that is defined to be the intangible and general designs emerging in a mind that belongs to an object or thought, has become both subject and object of a very large field ranging from philosophy to linguistics, from social sciences to science. Regardless of which field is in question, the unity of concept is important in order to pave the way for a right understanding and effective agreement between parties. In other words, when a concept is expressed or indicated, the same things need to appear in the mind of people who are the addressees of the relevant concept. When this circumstance does not come true, it may result in misconceptions, and misunderstandings accordingly. Language teaching is one of the fields in which the concepts are confused and used wrongly. The aim of this study is to eliminate the misconceptions and misunderstandings of concepts by providing the literature definitions and scope fields of some basic concepts of Turkish language teaching as a foreign language in special and in general terms. According to the results of the study, it has been identified that a common equivalence has not been ensured for the concept of "Common European Framework of Reference for Languages: Learning, Teaching and Assessment." It has been revealed that this kind of problems regarding the concepts, emerge because of the differences of translations that are done from foreign languages to Turkish language.
\end{abstract}

Keywords: language teaching, foreign language teaching, Turkish language teaching as a foreign language, concept

\section{Introduction}

Discussions have been made since the 4th-5th centuries B.C. about what concept is in several fields especially in philosophy. A complete consensus has not been built about what concept is for thousands of years. However, it can be observed in the literature that the concept is generally defined as a variable that points out the common features of different objects and events, or that indicates a group whose members are different (Ülgen, 2004). Although a consensus has not been built about what is concept, it seems that the researchers agree about the fact that misconceptions have a negative impact upon understanding.

In order to understand a subject or theory better, the concepts that belong to the relevant field need to be identified well. In other words, the terms and expressions of such concepts need to be explained in such a way that they will be understood clearly by everyone without any ambiguity and confusion (Küçük \& Demir, 2009). Interesting results have been obtained in the studies conducted in Turkey about the concepts that play an important role in accomplishing an accurate understanding and having an effective consensus. The relevant studies identified that several concepts are conceptualized wrongly or deficiently and consequently that serious problems emerge in terms of understanding and having a consensus (Sağır, 2007; Yükselir, 2006; Benhür, 2002; Turan, 2002; Yontar, 1991). Therefore, there are concepts that we frequently encounter in foreign language teaching in general, and in teaching of Turkish as a foreign language. Having knowledge about the scope field and content of such concepts will be helpful about recognizing, understanding and comprehending the field. Common European Framework of Reference for Languages, Language Development Portfolio / European Language Portfolio, Language Passport, Language Learning Background / Language Biography, Portfolio, Language Level, Language, Native Language, Mother Tongue, Target Language, Foreign Language, Multilingualism, Culture, Multiculturalism, Cross-cultural Learning, Culture Transmission, Language Learning, Language Acquisition, Language Teaching, Step Based System, Requirement Analysis, Authentic Material, Special-Purpose Language Teaching are the important concepts of teaching Turkish language as a foreign language.

\section{Method}

Descriptive research method has been used in this study. Research method is a study method that describes a circumstance that is existing or that took place in the past as it is (Karasar, 2008). The data have been obtained by means of document scanning. Descriptive analysis has been utilized in the analysis of the data. In descriptive analysis, the obtained data are 
summarized or interpreted under the headings that were determined beforehand (Altunışık, et al. 2010). In accordance with descriptive analysis, first of all, a framework has been formed about the subject. Then, the concepts that are suitable for the framework have been determined, the concepts have been identified and finally, the usages of the concepts have been interpreted.

\section{Findings}

According to document analysis results, 20 commonly used concepts about teaching Turkish as a foreign language were identified. These concepts and the definitions of these consepts are presented below:

\subsection{Common European Framework of Reference for Languages}

European Union countries produce a series of new ideas and projects in order to accomplish the mutual works in the field of education which they previously accomplished in other fields. "Language learning" is one of these ideas and projects. Member states protect the language and culture of the countries and share this fact with other European countries. Furthermore, efforts are made in order to raise the awareness among European citizens about learning more than one foreign language. In order to make the proposed ideas tangible, "Department of Modern Languages" (Sektion 'Moderner Sprachen'), which is an effective organ of European Council, materializes the language policies of the Council and the decisions taken here are made coherent with the education systems of the Member States (Güler, 2005). Common European Framework of Reference for Languages has been prepared and carried out with the purpose of encouraging the individuals living in Europe to learn more than one language and supplying the necessary need to ensure the continuity of multilingualism and multiculturalism in European continent (Arslan and Coşkun, 2012). This written work is composed of 260 pages and 9 sections. The $1^{\text {st }}$ section states the functions of Common Framework of Reference for Languages and expresses the general language policy of Council of Europe, popularizes the multilingualism, tackles the importance of transmitting the linguistic and cultural difference of Europe and sorts the necessary criteria for all these elements. The $2^{\text {nd }}$ section explains the details of "action-oriented" language learning approach. The $3^{\text {rd }}$ section is about the definition of language use levels and language use competence levels. The $4^{\text {th }}$ section explains the status, fields, institutions and context of language learning, and the connections of individuals related to such factors. The potential skills that need to be owned by a user of Common Framework of Reference for Languages or a language student are explained in the $5^{\text {th }}$ section. The skills that they may improve within the process of language learning are also explained in the same section. The $6^{\text {th }}$, $7^{\text {th }}$ and $8^{\text {th }}$ sections explain the relationship between "acquiring" and "learning" that are directly related to the language learning and language teaching processes of the text. They also offer suggestions in order to improve the multilingualism ability of the individual. The $9^{\text {th }}$ section, that is the last one, explains the concepts of measuring and assessment in detail considering especially the validity and reliability (Uzun, 2005 op cit., Kır, 2011).

Common European Framework of Reference for Languages We believe that Common European Framework of Reference for Languages, which includes learning, teaching and assessment, needs to be assessed as a concept due to the fact that it is used as a base in Europe in foreign language teaching and teaching of Turkish as a foreign language and that its expression needs to be used as an equivalent concept in the field. This is because there is not any consensus about Turkish translation of the text in the literature. It has been identified that different confusions took place about translation. The headings identified are as follows: Program of Common European Framework of Reference for Languages, Common European Framework of Reference for Languages: Learning, Teaching and Assessment, Common European Framework of Reference for Languages, Learning - Teaching - Assessment, Council of Europe's Common European Framework of Reference for Languages, Common European Framework for Teaching Languages, Common European Framework of Reference for Languages, Teaching and Assessment, Council of Europe's Framework Program on Common Language Criteria, Common European Framework of Reference for Languages: Learning, Teaching, Assessment. A unit has not been ensured about the name of the text in both two different versions of the text that was published in Turkey by the Ministry of National Education. Common European Framework of Reference for Languages that was translated in 2009: Education, Educating, Assessment (MEB (Ministry of National Education), 2009) title has been used but the Common European Framework of Reference for Languages that was translated in 2013: The title of Learning, Teaching and Assessment (MEB, 2013) has been used. At this point, it can be stated that an association is needed about Turkish equivalent of the text in order not to cause any concept contradiction.

\subsection{Language Development Portfolio/Language Portfolio}

Common European Framework of Reference for Languages that aimed the standardization and to be systematic in language teaching within the scope of the activities of "European Year of Languages" in 2001. Common European Framework of Reference for Languages (Learning, Teaching, Assessment) has been prepared. Language Development Portfolio / European Language Portfolio has been prepared in compliance with the text within the same year.

The aim of European Language Portfolio is to encourage European citizens for multilingualism and multiculturalism, and to direct them to learn the first foreign language in primary school, the second foreign language in secondary school and 
the third foreign language at university (Genç, 2004). European Language Portfolio does not have the feature of being a course book or a reference book. This portfolio that is accepted to be a file belongs to the person who is learning, is a tool that enables the individuals to learn which skills at which level they need to improve themselves throughout the foreign language learning process in or out of the school. It also paves the way for individuals to participate in the entire foreign language learning process from planning to assessment (http://adp.meb.gov.tr/nedir.php).

Language Portfolio is composed of three sections: Language Passport, Language Learning Background / Language Biography, Portfolio.

\subsubsection{Language Passport}

This document that is a part of European Language Portfolio, is a record of the language skills, qualifications and experiences that are acquired in language learning process. Language Passport indicates the languages and skills which the owner of language passport is competent at. The content of the language passport is as follows:

- Profile of the languages that were learnt by the owner of passport while growing,

- Language skill profile that is identified according to European Common Framework Program,

- Summary of language learning experiences,

- Summary of linguistic and cross-cultural experiences,

- Records of certificates and diplomas (Council of Europe, Language Passport, 2010).

Language Passport is a section that is determined depending on skills and common reference levels of the individual within the framework of European Framework. It also gives information about the knowledge of the individual in terms of different languages in a specific period of time. In this passport, official features are recorded and are defined through the important linguistic and cross-cultural learning experiences which also include language, skills, and partial or certain information(Güneyli and Demirel, 2006). The features regarding the content of language passport is demonstrated below:

a. Profile of the languages that were learnt by the owner of passport while growing

There is no condition of proving on the markings and writings made on language passport (except for government agencies). Declaration of the individual is accepted to be essential. The table below displays the languages that individuals learn while growing.

Table 1. Profile of the languages that were learnt by the owner of passport while growing

\begin{tabular}{|c|c|c|}
\hline \multicolumn{3}{|c|}{$\begin{array}{l}\text { Language(s) I used or use within my family and neighbourhood } \\
\text { Aile içinde ve yakın çevremde kullanmış ve kullanıyor olduğum dil(ler) }\end{array}$} \\
\hline $\begin{array}{l}\text { Language } \\
\text { Dill }\end{array}$ & $\begin{array}{l}\text { Listening/Speaking } \\
\text { Dinleme/Konuşma }\end{array}$ & $\begin{array}{l}\text { ReadingNriting } \\
\text { Okuma/Yazma }\end{array}$ \\
\hline Example $1 \ddot{O}_{\text {inch }}$ & $\sqrt{ }$ & $\checkmark$ \\
\hline
\end{tabular}

(Source: Council of Europe, Language Passport, 2010).

The owner of passport writes down the languages that she/he has learnt at home or by her/his peers while growing and states her/his field of skill.

\section{b. Language skill profile that is determined according to Common European Framework}

Table 2. Self-evaluation of the owner of passport within or out of formal education

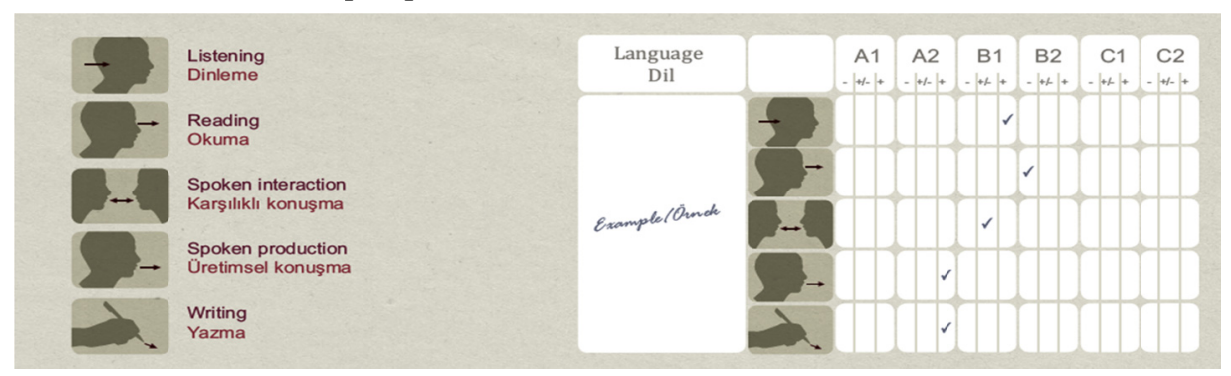

(Source: Council of Europe, Language Passport, 2010).

In the language passport sample above, there is a self-evaluation about the language that was learnt by the owner of the passport within or out of formal education. The owner of the language passport marks her/his own proficiency level at 
her/his own will according to self-evaluation table. According to the sample table above, the owner of the relevant language passport has the following features;

$\mathrm{S} /$ he has B1 level of listening ability (I can understand the main lines of clear and standard speeches about familiar subjects that are frequently encountered at workplace, school and leisure time. I can understand the main lines of most of radio and TV programs with respect to current issues and my field of interest when they are slow and clear.)

- has B2 level of reading ability (I can read the articles and reports in which the specific attitude or view of a writer is adopted, which are about current issues. I can understand a contemporary literary prose.)

- B1+/- level of dual conversation ability (I can deal with many problems that may emerge in the country where the relevant language is spoken. I can attend the conversations about my fields of interest or daily life (such as family, hobby, work, journey or current issues) without making any preparation.)

- Has A2+ level of productional speaking ability (I can use a series of sentences in order to describe my family, other people, living conditions, my educational background and my latest job with a simple language.)

- Has A2+ level of writing (I can write short, simple notes and messages. I can write short and personal letters such as letter of acknowledgements.)

We understand that the relevant individual preferred the appropriate option and marked the convenient option accordingly (http://adp.meb.gov.tr/nedir.php).

\section{c. Summary of language learning experiences}

This page lists the language courses that made contribution to the owner of Language Passport.

Table 3. Language learning status of the owner of language passport in the level of primary school education

\begin{tabular}{|c|c|c|c|}
\hline $\begin{array}{l}\text { Language } \\
\text { Dil }\end{array}$ & $\begin{array}{l}\text { Details } \\
\text { Detaylar }\end{array}$ & $\begin{array}{l}\text { From } \\
\text {-den }\end{array}$ & $\begin{array}{c}\text { To } \\
\text {-e kadar }\end{array}$ \\
\hline
\end{tabular}

(Source: Council of Europe, Language Passport, 2010).

A table is demonstrated in language passport starting from primary school education for each formal education level. Furthermore, another table is presented for other courses apart from formal educational institutions.

\section{d. Summary of linguistic and cross-cultural experiences}

Table 4. Languages that are spoken by the language passport owner for education or courses

\begin{tabular}{|c|c|c|c|}
\hline Using languages for study or training / Eğitim veya kurslar için kullandığım/kullanıyor olduğum diller \\
\hline Language & Details & From & To \\
Dil & Detaylar & -den & -ekadar \\
\hline
\end{tabular}

(Source: Council of Europe, Language Passport, 2010).

In this section of Language Passport, the individuals are expected to mark their cross-cultural experiences in the country/countries in which the foreign language learnt by the individual is spoken as a native language or not. In addition to the table above, tables are also presented in language passport under the headings of "The languages that I used/am using regarding my business", "The languages that I used abroad during my long-term stay or visit, "Mediating between languages by staying in between various languages (Multi-lingual groups, doing informal translations)", "Other fields that I used".

e. Records of certificates and diplomas

Table 5. Records of certificates and diplomas owned by the language passport owner

\begin{tabular}{|c|c|c|c|c|c|c|c|c|}
\hline \multirow{2}{*}{$\begin{array}{l}\text { Language, and language } \\
\text { activity (ies) if applicable } \\
\text { Eger varsa dil ve } \\
\text { dil aktivite(ler)i }\end{array}$} & \multicolumn{6}{|c|}{$\begin{array}{l}\text { Level } \\
\text { Dürey }\end{array}$} & \multirow{2}{*}{$\begin{array}{l}\text { Title / Institution } \\
\text { Başlik / Kurum }\end{array}$} & \multirow{2}{*}{$\begin{array}{c}\text { Year } \\
\text { Yil }\end{array}$} \\
\hline & A1 & A2 & B1 & B2 & $\mathrm{C} 1$ & C2 & & \\
\hline & & & & & & & & \\
\hline & & & & & & & & \\
\hline & & & & & & & & \\
\hline
\end{tabular}

(Source: Council of Europe, Language Passport, 2010). 
There is a record table in this section involving the diplomas and certificates that the individual has been awarded. The information regarding the diplomas and certificates in Portfolio section of language development portfolio, are indicated in this table.

\subsubsection{Language Learning Background /Language Biography}

The second section of European Language Portfolio is composed of language learning background or language biography. Mirici (2016) presented the following information about this section of European Language Portfolio:

Language Learning Background is a record of the learner's background of foreign language and enables

the learner to determine the language learning objectives, to make progress in the relevant foreign

language by evaluating herself/himself depending on the common criteria.

Foreign Language Curriculum Vitae is composed of four sections (http://adp.meb.gov.tr/nedir.php):

a. Story of language learning

In this section, the individual records the information regarding the schools and courses at which the relevant foreign language has been learnt. The necessary explanations with respect to the filling are given in the beginning of the relevant tables.

\section{b. Assessment of language learning process}

In this section, the efforts are made to enable individuals to learn the learning process by helping them about realizing what kind of a learner they are. In this section, if necessary, the teachers and parents need to help the children in identifying the proper learning models and marking the appropriate place.

Identification of a learning model for the individual will make it easier for the teacher to help the individual in teaching activities.

\section{c. Language and cross-cultural experiences}

In this section, the children will keep a record about how they learnt the relevant foreign language and reflect their experiences regarding the various cultures. The explanations on how to fill the tables are written in the relevant chapters of this section.

\section{d. Personal language accomplishments}

In this section, the individual will determine what she/he can do in the relevant foreign language at which level and assess herself/himself in terms of the proficiency in the relevant foreign language. The ones that are selected by individuals as "I can do", represent their acquisitions. What they are not able to do yet, are their objectives. In this way, the objectives of the program also become the objective of the child. The assessments belonging to the individuals here might be different from the assessments belonging to the teachers and parents. The individual will shape her/his studies having regard to the differences of this assessment. The teachers and parents strictly should not intervene the assessments of the student (http://adp.meb.gov.tr/nedir.php).

\subsubsection{Portfolio}

Portfolio is the part in which the personal studies documenting the accomplishments of the individual about foreign language learning are collected. The individual is allowed to put any study she/he would like to add. The individual updates it and replaces the previous studies with the new ones when necessary. They can use it in any job application or in applying to an educational institution. The individual can observe her/his own progression by checking her/his own studies in the portfolio(Güneyli and Demirel, 2006).

\subsection{Language Level}

Language level meets the usage level regarding a foreign language. Language skill levels, Council of Europe, Common European Framework of Reference for Languages. They are classified into three levels as (Learning, Teaching, and Assessment) Basic User (A), Independent User (B) and Proficient User (C). These levels are also classified into two sub-levels. Basic User Level, Breakthrough (A1) and Waystage (A2), Independent Level User, Threshold (B1) and Vantage (B2), Proficient User Level is Autonomous / Effective Operational Proficiency (C1) and Mastery (C2).

When it comes to the expression of language levels in teaching Turkish as a foreign language, mostly Basic (A), Intermediate (B) and Advanced (C) levels are preferred within the scope of Common European Framework of Reference for Languages. A1-A2, B1-B2, C1-C2 are the sub-statements that are used for sub-levels of these levels. 


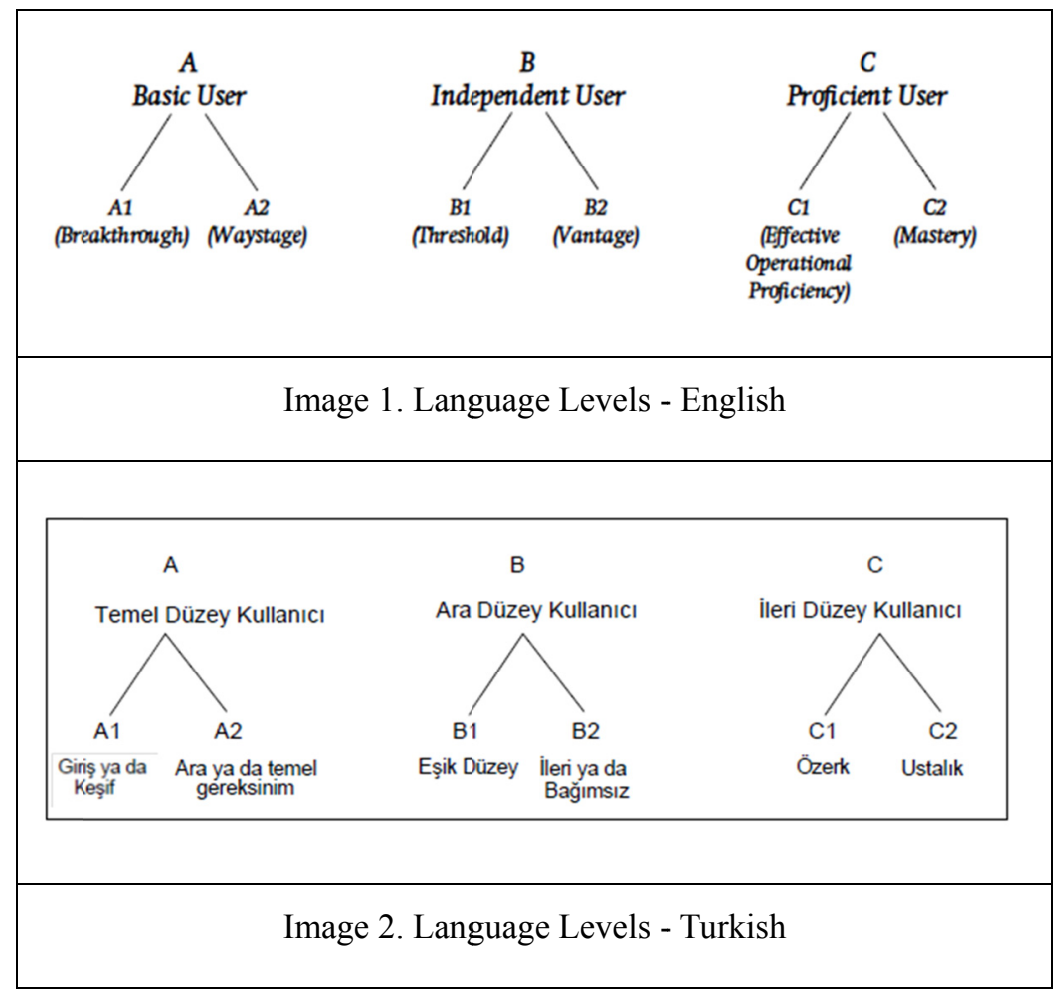

General language proficiencies and grammar contents that are expected from language levels are displayed in the following sections in detail. Common European Framework of Reference for Languages also provided the expected language proficiencies and grammar contents in the fields of language ability depending on each language level.

\subsection{Language}

Several definitions have been made so far about language that is the most basic agreement tool which is peculiar to human being. Language distinguishes the people from living creatures and other non-living creatures in the nature. Many books and articles have been written about this subject. The following definitions that were made about language concept came to the forefront in such studies:

"Language is a natural tool that provides to reach an agreement among people, is a creature having unique rules but developing around such rules, is a secret agreement system whose foundation was laid at unknown times and is a social organization that is weaved with voices." (Ergin, 1993). Aksan defines the language as "a magical asset; having multiple-purpose that is impossible to think about at in a moment, whose miscellaneous qualities emerge when you look into it from various angles and whose some secrets have not been solved even today." According to Aksan, "language is an institution that is found to be relevant with human being and society; and all other fields such as science, art, technique that cannot be thought to be separate from human being and society. It is also an institution that formed these elements." (Aksan, 1995).

Language is an integrity of passwords that are coded by the subjects that will establish the communication and it is used by these subjects in conveying messages to each other. In order to comprehend the meaning of these passwords completely, it is necessary to be a part of the relevant society (Ünalan, 2010).

"Language is a very important and indispensable communication tool that is used in expressing and teaching various ideas, emotions, attitudes, value judgements; transmitting the accumulation of culture concerning the events lived; asking question; giving order and making a request" (Özbay, 2001).

Based on the definitions above, it is understood that the most important function of language is to be a fundamental tool providing the communication bamong people. People can establish communication without language. However, it is an obvious fact that all the communication styles that are established without language will be deprived of certain elements because a healthy communication can only be established with language.

\subsection{Native Language}

The concepts of native language and mother tongue are frequently used for each other wrongly and the difference in their meanings are not distinguished a lot. Sağır (2007) sorted the definitions that clarified the concept of native language as follows: 
Today, the common language that paved the way for the unification of the languages and dialects, on an unknown date, which became different from each other more or less in terms of voice structure, shapes structure and meaning such as Latin language that became a source for Proto-Turkic, Proto-Mongolic, Pro-Altaic, Roman languages (Korkmaz 1992 op cit., Sağır, 2007).

Source language that constituted the source of the languages which are collected in certain linguistic groups and accepted to be relatives of each other. Altai language is accepted to be the native language of Turkish, Mongolian and Manchu-Tungusic. Latin language is a native language according to Roman languages (Topalaoğlu 1989 op cit., Sağır, 2007). The language that created other languages. For example, Latin language is a native language for Roman languages. Primarily Yakut and Chuvash languages, the Turkish languages and dialects also come from a native language whose beginning is not known (Koç 1992 op cit., Sağır, 2007). The language that paved the way for the birth of one or many languages. For example, Latin language is a native language for Roman languages (Vardar 1988 op cit., Sağır, 2007). For the concept of native language, the equivalent of "the language that derived other languages and dialects apart from itself" is written in Turkish Dictionary.

\subsection{Mother Tongue}

"Language is the most powerful connection that transforms a society into a nation. It tightly links the individuals with their nation, homeland and history. Language is inherited from generation to generation and makes the individual a ring of the chain between past and future" (Aksan, 1995). What is described in these statements is apparently the mother tongue. According to Aksan, "mother tongue is taught by mother and immediate vicinity in the beginning, then by the associated environment. It is embedded in the subconscious of people forms the most powerful links of individual with society" (Aksan, 1975).

"The foundations of mother tongue are laid in the first fifteen years, the building is established on this foundation in the following fifteen years, the following fifteen years involve the furnishing, decorating and enriching years of the building" (Tural, 2000: 4). Accordingly, the acquisition of mother tongue starts in babyhood period and its foundations are laid in childhood period. According to Ünalan (2010), mother tongue is an important factor for the improvement of personality of individuals increasing the knowledge and ability and complying with society. People acquire their mother tongues by their mothers, fathers and relatives. Then, they learn it from the people they contact As a changing creature, human being starts to obtain the first culture accumulation by means of mother tongue.

Based on the above mentioned definitions of native language and mother tongue, it is observed that the concept of native language needs to be preferred (including the teaching Turkish as a foreign language) instead of the concept of mother tongue when it comes to Turkish education and Turkish teaching.

\subsection{Target Language}

"Target language" is used for the equivalent of the language that is taught or desired to be taught. In case two languages are used together, the language that is owned by learners can be described as "source language" whereas the language that is taught/learnt is described as "target language." The equivalent of target language is Turkish language in teaching Turkish as a foreign language.

\subsection{Foreign Language}

Each language apart from the native language is foreign language. Foreign language is different from the native language that is acquired naturally by individual and available nearby the individual just after the birth. Furthermore, foreign language may not be used as a communication tool in a society in which the individual lives. Foreign language is used while establishing communication with the individuals who acquired the relevant language as a native language or who learnt that language as a foreign language as a result of a conscious and planned learning process. (Erden, 2005). In short, foreign language can be defined as the language which is different from native language and acquired by means of teaching instead of the way of acquisition.

\subsection{Multilingualism}

Multilingualism has gained great importance in recent years within the Council of Europe's approach of language learning within the context of the individual. Multilingualism within the 'individual context' is very different from multilingualism within 'social context' that means being able to speak a series of languages or using various languages in a society at the same time. In social context, multilingualism can be acquired by diversifying the knowledge of foreign language to be offered to the student at school or educational institutionsby directing the student to know more than one foreign language or restricting the dominant role of English language in international communication. On the other hand, in individual context, multilingualism can involve even the languages of communities-it can be acquired at school or as a direct experience-(in cultural context) acquired- apart from local language. Individuals do not keep these language in a cognitive mental section but has the ability of communication that is able to ensure these languages to be in a mutual 
communication and interaction. Individuals have flexibility to use the different features of the abilities they have in order to establish an effective communication with a speaker under different circumstances. For example, the speakers swift from one language or dialect to another in order to express themselves and to understand the people they contact. They can also use the language or dialect in different ways in order to compose more than one written or oral text by recalling the words that exist in mutual accumulation of international field. People who have even some of such information can use a common language. In the circumstances where this mediator is not available, the individuals reveal all linguistic and paralinguistic (mimic, gesture, facial expression) features and simplify the use of language when necessary (MEB, 2009, 3-4- Common European Framework of Reference for Languages: Learning, Teaching, and Assessment).

\subsection{Culture}

From past to present, the individuals' need of feeling themselves belonging to a community or culture has been considered as one of the prerequisites of being a nation. To put it simply, culture is the existence objective of individuals. Culture also means language, religion, customs and traditions, shortly the accumulation of values which are perceived as the existence, union and continuation reasons for a society. It also means habits, attitudes, delights but most importantly, it is a way of democracy and life style. Culture that comprises literary and artistic products in its structure, is transmitted from generation to generation. It is open for change, has an integrative structure and informs about the feelings of belonging and dependence (Küçük, 2011).

\subsection{Multiculturalism}

Multiculturalism means living in a society with various cultures together within the framework of harmony and tolerance. The concept of multiculturalism is a concept that has become a current issue with the concept of multilingualism. The language policy of Europe paved the way for the emergence of this concept.

\subsection{Cross-cultural Learning}

Accepting each other, linguistic and religious pluralism, respect and tolerance are essential in cross-cultural learning that can be identified as obeying a specific cultural structure or assimilating that structure depending on the interaction and communication that are linked with upper-cultures and sub-cultures which are established by the individuals who have different or similar cultural values with each other on the same piece of land. Universal values should also be adopted based on the external factors as well as national values belonging to sub-cultures or upper-cultures (Illkhan 1995 op cit., Küçük, 2011).

In cross-cultural learning that aims to include the differences in whole and is composed of the unification of different values, making a compromise on the subjects of important elements, reciprocal values, beliefs, attitudes, written and oral literature, language, music, religion, moral, aesthetic values and being tolerant to different cultures and identities. The aim is to protect the mutual cultural heritage, unite pluralist values, understand opponent and homogeneous culture(s), interiorise such cultures, eliminate various prejudices arising from history, geography or culture: realise social coalescence, develop empathy towards others, protect cultural diversity without damaging the national culture and become integrated with common/upper culture successfully (Küçük, 2011).

\subsection{Culture Transmission}

Culture transmission means the transmission of the culture (material or non-material set of values) owned by a society from generation to generation and adopting such cultures. Evaluating this concept within the field of foreign language teaching, it can be identified as conveying the culture that belongs to the language taught to the language learners by means of the texts and material of sub-culture. Culture transmission plays a significant role in foreign language teaching. Language teaching cannot be fulfilled completely if the culture elements belonging to the target language are not included in language teaching. The ways of solving the logic of language and having knowledge about the relevant language are based on having an extensive knowledge about the contents of culture codes .

While implementing a culture transmission in teaching Turkish as a foreign language, mostly the vocabulary, proverbs and sentences that are frequently used in daily life are tackled. For example; more power to your elbow, same to you, may god speed you etc. Thesevocabulary join the teaching process by means of the texts in course books that constitute the foundation of the courses. Features are taught through proverbs and idioms that are important culture elements for foreign people who learn the relevant language at an advanced level. The course books that are used in teaching process are also utilized to a great extent (Erdem, Gün and Karateke 2015).

\subsection{Language Learning}

When we evaluate the learning as an active process in which new meanings are formed with the prior knowledge of the student by associating and integrating the new information (Güneş, 2007), language learning may also be identified as the process of creating new contents by compounding the new information regarding the language with the previous ones. 
According to Tura (1983), "foreign language learning means acquiring new sequence that is composed of meanings and sounds, learning different styles of communication functions by means of speaking rules regarding this sequence and using them appropriately and validly. Foreign language teaching is a whole of studies that aim to inform and direct the student in the stage of acquiring a new language sequence."

\subsection{Language Acquisition}

The concept of language acquisition was mostly tackled within the concept of mother tongue. However, nowadays it has become a concept field that is tackled independently, and studies are conducted about this subject. The concept of language acquisition has also been included in the literature within the scope of foreign language acquisition as well as the scope of mother tongue acquisition. Language acquisition means the individual's acquiring the language rules, vocal properties and words spontaneously since birth. Language acquisition starts in a natural process spontaneously. It takes place with the vicinity of language that is closely contacted by the individual. Language acquisition is completed to a great extent until the school age period. After school age, it still continues relatively on a low level but systematically. Foreign language acquisition emerges when people acquire any other language as well as the native language.

\subsection{Language Teaching}

Language teaching is a process that involves the implementation of language learning activities that are conducted within the context of objectives and within the compass of a certain program in school age period. Language teaching can also be defined as a whole of activities that ensure a systematic transmission of knowledge and skills belonging to speaking, reading, writing, listening and grammar fields of language.

\subsection{Step Based System}

"Step based system" is one of the innovations that was accomplished in foreign language teaching in Turkey. Step based system was adopted in 1988. It is composed of six steps and the duration of each step corresponds to an academic year. The first step is compulsory and the rests are on student's will. After each step, the students who become successful in the exams held at the end of the year receive a certificate. Furthermore, the language can be changed in this system. The classroom size is minimum 8 and maximum 25 in foreign language courses. Weekly course hours were determined as five hours. Students need to receive 70 points out of 100 points in order to be regarded successful in the exams that are held at the end of the year through host system (Özdemir, 2006). A different system failed due to the problems arising from the implementation. It was cancelled in 1989-1990 academic year and previous practices were adopted again. Foreign language courses were made non-compulsory at regular high schools in 1988-1989 academic year and turned into elective courses (Demircan,1988 op cit., Özdemir, 2006).

\subsection{Needs Analysis}

Needs analysis was used for determining the knowledge and skills that are necessary in order to increase productivity and efficiency in business world especially. In recent years, it has become a concept that is used in the field of foreign language teaching. In the studies which were conducted in the field of needs analysis with respect to language teaching (Çalışkan and Çangal, 2013), the fulfilment of requirement analysis studies are demonstrated as an obligation in teaching approaches that relocate the student to the center. The aim of requirement analysis is to identify the needs of learners that inform about how to organize a course. It also aims to determine the needs of learners which relatively remained at theoretical level.

In light of these findings, it will be possible to prepare an effective program for Turkish teaching field for foreigners, to create educational materials suitable for the needs, plan the education of students depending on their ages, genders, occupations and ethnic origin and conduct measurement-assessment studies fitting for purpose (Çalışkan and Çangal, 2013).

\subsection{Authentic Material}

Recently, the use of authentic material has become popular in teaching of Turkish as a foreign language. The use of authentic material in teaching of Turkish as a foreign language makes the language teaching more effective and functional. "Authentic materials are the materials that were (not) composed with the purpose of teaching but received from authentic communication environments (Geddes and White, 1978 op cit., Güner and Belet Boyac1, 2015). "Authentic materials are; films television programs, music/video (clips) - radio conversations - interviews, songs - radio games - newspaper/journal articles, cartoons movies - advertisements/announcements - general handbills - brochures, various forms - train/ship tariffs - price lists, programs - airplane/train/bus/museum/concert tickets and guidebooks-bills of fare/recipes" (Od, 2013 op cit., Güner and Belet Boyac1, 2015).

\subsection{Special-purpose Language Teaching}

Students take place in the center of special-purpose language teaching programs. What to teach students is determined 
according to the answers students give to the questions of why they want to learn a foreign language (Temizyürek, Çangal, Yörüsün, 2015). In special-purpose language teaching, special interest fields or work/field of business of the individual are taken into consideration. Nowadays, teaching of Turkish as a foreign language is mostly conducted with general-purpose programs. Teaching of Turkish as a foreign language has started to be conducted recently. There are only a limited number of studies related to this field.

"Teaching of Occupational Turkish" can be given as an example for teaching Turkish as a special-purpose foreign language. Special-purpose Turkish teaching is divided into sub-branches such as teaching of occupational Turkish, teaching of press and media, teaching of tourism Turkish and teaching of educational Turkish. There are several foreign companies that provide service for Turkish speakers and there are various Turkish companies that employ Turkish employees. Foreigners who work in these fields need to learn Turkish expressions, idioms, words and concepts rather than general Turkish in order to make their business lives more efficient. With respect to occupational Turkish, a foreigner working in banking sector needs to learn Turkish terms about banking sector (Temizyürek, Çangal, Yörüsün, 2015).

\section{Conclusion}

Please indicate the aim of the study in the first sentence and the give a little information about the data collection and analysis tools.

In this study, the basic concepts of Turkish teaching as a foreign language such as Common European Framework of Reference for Languages, Language Development Portfolio/European Language Portfolio, Language Passport, Language Learning Background/Language Biography, Portfolio, Language Level, Language, Native Language, Mother Tongue, Target Language, Foreign Language, Multilingualism, Culture, Multiculturalism, Cross-cultural Learning, Culture Transmission, Language Learning, Language Acquisition, Language Teaching, Step Based System, Requirement Analysis, Authentic Material, Special-Purpose Language Teaching have been described. The use of these concepts within the direction of th definitions will help to prevent the misconceptions and fallacies in the field. The following identifications have been made about the concepts of Turkish teaching as a foreign language:

Several signifieds have been identified in "Common European Framework of Reference for Languages" arising from translation. Although the signifier is mutual, the fact that there are various signifieds may result in misconceptions in mind. These misconceptions also result in moving away from the unity of of literature. It can be stated the expression of "Common European Framework of Reference for Languages: Learning, Teaching and Assessment" needs to be translated into Turkish as "Diller için Avrupa Ortak Başvuru Metni: Öğrenim, Öğretim ve Değerlendirme" in order to ensure the unity of literature, in order to ensure the unity of literature.

The equivalents of the expressions of Language Development Portfolio and Language Portfolio are also used for the same concepts in Turkish. These expressions are also frequently used for each other in the literature. It can be stated that "Language Development Portfolio" needs to be preferred in order to ensure the unity of literature.

The equivalents of the expressions of Language Learning Background and Language Biography also mean the same signified in Turkish language. Therefore, the equivalent of "Language Development Portfolio" needs to be preferred in Turkish language instead of using two different expressions.

It has been identified that the unity has been ensured in Turkish language about the equivalents of the concepts of Basic User (A), Intermediate (B) and Advanced / High (C) Levels within the scope of language skill level concept. Each level is divided into two sub-branches in itself as it is stated in the findings. These sub-branches are preferred to be coded with letters and numbers in the literature instead of words. In other words, (A1) coding is used instead of the concept of Breakthrough that means one of the sub-branches of Basic language skill. A1-A2, B1-B2, C1-C2 means the language skill levels and there is not any misconception in the field about this equivalence.

Mother tongue and native language are another concepts that lead to misconception. The definitions of these two concepts have been made in findings section. The signified was different in the above mentioned concepts whereas the signifier was the same. However, the signified and signifier are separate in these two concepts. Thus, these two concepts should not be used instead of each other.

Target language, foreign language, multilingualism, culture, multiculturalism, cross-cultural learning, culture transmission, language learning, language acquisition, language teaching, step based system, requirement analysis are the concepts of Turkish teaching as a foreign language whose histories date back to old times. However, authentic material, special-purpose language teaching are the new concepts of Turkish teaching as a foreign language.

The aim of this study, which is about certain basic concepts of Turkish teaching as a foreign language in private and foreign language teaching in general, is to eliminate the misconceptions in the field. The next studies can define other concepts, can identify frequency of use of concepts based on the literature. 


\section{References}

Aksan, D. (1975). Anadili. Türk Dili, 285, 423-434.

Aksan, D. (1995). Her yönüyle dil, ana çizgileriyle dilbilim. Ankara: TDK.

Altunışık, R., Çoşkun, R., Yıldırım, E., \& Bayraktaroğlu, S. (2010). Sosyal bilimlerde araştırma yöntemleri. Sakarya: Sakarya Kitabevi.

Arslan, A., \& Coşku, A. (2012). Avrupa dilleri ortak çerçeve programı: Türkiye ve dünyada neler oluyor? AİBÜ Sosyal Bilimler Enstitüsü Dergisi, 12(20), 1-19. http://dx.doi.org/10.14520/adyusbd.394

Benhür, M. H. (2002). Türkçenin yabancılara ögretiminde tartışllmayan ana kavramlar, Gazi University Institute of Education Sciences, Unpublished PhD Thesis.

Çalışkan, N., \& Çangal, Ö. (2013). Yabancilara Türkçe öğretiminde dil ihtiyaç analizi: Bosna-Hersek örneği. Abant İzzet Baysal Üniversitesi Eğitim Fakültesi Dergisi, 13(2), 310-334.

Council of Europe. (2001).Common European Framework of Reference for Languages: Learning, Teaching, Assessment

Council of Europe. (2010). Language Passport.

Erdem, M. D., Gün, M., \& Karateke, B. (2015). İleri seviye için hazırlanan Istanbul yabancılara Türkçe öğretim setinin kültür aktarımı açısından incelenmesi. International Journal of Language Academy, 3(1), 8-17. http://dx.doi.org/10.18033/ijla.214

Erden, H. (2005). İngilizce dilbilgisi ögretimi ve yöntemler: İngilizce'nin yabancı dil olarak öğretiminde sinıf içi dilbilgisi ögretimine yabancı dil öğretim yöntemlerinin bakış açılarının karşılaştırmalı incelemesi. Ankara University Institute of Social Sciences, Unpublished Master's Thesis.

Ergin, M. ( 1993) . Türk dil bilgisi. İstanbul: Bayrak.

Genç, A. (2004). Türkiye'de ilk ve ortaöğretim okullarında yabancı dil öğretimi. Bişkek, Kırgızistan-Manas Sosyal Bilimler Dergisi, 10, 107-111.

Güler, G. (2005). Avrupa konseyi ortak dil kriterleri çerçeve programı ve Türkiye'de yabancı dil öğretim süreçleri. Trakya Üniversitesi Sosyal Bilimler Dergisi, 6(1), 89-106.

Güner, M., \& Belet, B. Ş. D. (2015). Türkçe dersinde dinlediğini anlama becerisinin geliştirilmesinde otantik görev temelli otantik materyallerin etkisi. Turkish Studies International Periodical for the Languages, Literature and History of Turkish or Turkic, 10(11), 757-772.

Güneş, F. (2007). Yapılandırıcı yaklaşımla sınıf yönetimi. Ankara: Nobel Yayın Dağıtım.

Güneyli, A., \& Demirel, Ö. (2006). Dil öğretiminde yeni bir anlayış: Avrupa dil gelişim dosyası uygulaması. Cypriot Journal of Educational Sciences, 2(2), 110- 118.

Karasar, N. (2008). Bilimsel araştırma yöntemi: kavramlar, ilkeler, teknikleri. Ankara: Nobel Yayın Dağıtım.

Kır, E. (2011). OBM (ortak başvuru metni) bağlamında dil öğretmeni eğitimi ve Türkiye'deki uygulamaları, Ankara University Institute of Social Sciences, Unpublished PhD Thesis.

Küçük, A., \& Demir, B. (2009). İlköğretim 6-8. sınıflarda matematik öğretiminde karşılaşılan bazı kavram yanılgıları üzerine bir çalışma. Dicle Üniversitesi Ziya Gökalp Eğitim Fakültesi Dergisi, 13, 97-112.

Millî Eğitim Bakanlığı (2009). Diller için Avrupa ortak başvuru metni: öğrenme, öğretme, değerlendirme.

Millî Eğitim Bakanlığı (2013). Diller için Avrupa ortak öneriler çerçevesi: öğrenim, öğretim ve değerlendirme.

Mirici, İ. H. (2016 ). Avrupa dilleri öğretimi ortak çerçeve programı ve Avrupa dil portfolyosu nedir? http://adp.meb.gov.tr/nedir.php last access date: 17.01.2016

Özbay, M. (2001). 0-6 yaş grubu çocuklarındaki dil gelişiminin türkçe öğretimi açısından önemi. Bilig, 17, 98-103.

Özdemir, E. S. (2006). Yabancı dil öğretiminde yeni yönelimler. Cukurova University Institute of Social Sciences, Unpublished Master's Thesis.

Sağır, M. (2007). Ana dil mi, ana dili mi? Turkish Studies / Türkoloji Araştırmaları, 2(2), 540-544.

Temizyürek, F., Çangal, Ö., \& Yörüsün, S. (2015). Yabancılara Türkçe öğretiminde iş Türkçesi öğretim programı, ders kitabı ve terimler sözlüğ̈ denemesi: bankacılık örneği. Zeitschrift für die Welt der Türken/Journal of World of Turks, $7(2), 87-111$.

Tural, S. K. (2000). Düşünmek, eleştirmek ve eleştirilmek bir ihtiyaçtır. Bilge, 24, 3-6. 
Turan, İ. (2002). Lise coğrafya derslerinde kavram ve terim öğretimi ile ilgili sorunlar. G.Ü. Gazi Ĕgitim Fakültesi Dergisi, $22(2), 67-84$.

Ülgen, G. (2004). Kavram gelişstirme (kuramlar ve uygulamalar). Ankara: Nobel Yayınları.

Ünalan Ş. (2010). Dil ve kültür. Ankara: Nobel Yayınları.

Yontar, A. (1991). Farklı yaş gruplarındaki öğrencilerin bilişsel gelişim ve kavramsallaştırma düzeyleri. Eğitimde Arayışlar 1. Sempozyumu-Eğitimde Nitelik Geliş̧tirme. 13- 14 Nisan, 1991. İstanbul.

Yükselir, A. (2006). İlköğretim 6. sınıf sosyal bilgiler programında geçen kavramların kazanımı ve kalıcıll̆ğnda kavram analizi yönteminin etkisi.. Cukurova University Institute of Social Sciences, Unpublished Master's Thesis.

\section{(cc) Br}

This work is licensed under a Creative Commons Attribution 3.0 License. 